\title{
Population growth and within-plant distribution of the striped mealybug Ferrisia virgata (Cockerell) (Hemiptera, Pseudococcidae) on cotton
}

\author{
Martin D. Oliveira ${ }^{1}$, Christian S. A. Silva-Torres ${ }^{1}$, Jorge B. Torres ${ }^{1,3}$ \& José E. Morais Oliveira ${ }^{2}$
}

\author{
'Departamento de Agronomia, Universidade Federal Rural de Pernambuco, Rua Dom Manoel de Medeiros, s/n, Dois Irmãos, 52171-900 Recife-PE. \\ martindo@uol.com.br, christian@depa.ufrpe.br \\ ${ }^{2}$ Embrapa Semiárido BR 428, Km 152, Zona Rural - Caixa Postal 23, 56302-970 Petrolina-PE. jose.eudes@cpatsa.embrapa.br \\ ${ }^{3}$ Corresponding author: jtorres@depa.ufrpe.br
}

\begin{abstract}
Population growth and within-plant distribution of the striped mealybug Ferrisia virgata (Cockerell) (Hemiptera, Pseudococcidae) on cotton. The striped mealybug, Ferrisia virgata (Cockerell) (Hemiptera, Pseudococcidae), is a widely distributed and polyphagous pest species, which naturally occurs on cotton plants in Brazil. This study evaluated the establishment and population growth as well as the within-plant distribution of F. virgata on four cotton cultivars: CNPA 7H (white fibers), BRS Verde, BRS Safira, and BRS Rubi (colored fibers). The experiment was conducted in a complete randomized design with four treatments (cultivars) and 18 replications of each. Thus, cotton plants of each cultivar were infested with 100 newly hatched nymphs of $F$. virgata. The number of adult female mealybugs and the total number of mealybugs per plant were quantified, respectively, at 25 and 50 days after infestation. The developmental and pre-reproductive periods were also determined. Furthermore, we verified the distribution of $F$. virgata on the plant parts at 25 and 50 days after infestation. Ferrisia virgata showed similar growth of 412 -fold in the four cotton cultivars studied. Also, the nymphs were spread on infested leaves; the secondgeneration nymphs were spread and established in all plant parts. Our results characterize $F$. virgata as having much potential as an important cotton pest in Brazil.
\end{abstract}

KEYWORDS. Colored fiber cotton; Gossypium hirsutum; host susceptibility; Insecta.

Several species of herbivores have been recorded as cotton pests of greater or lesser importance depending on the region. The mealybugs (Hemiptera, Pseudococcidae) are outstanding for causing loss of yield of cotton crops in several countries (Fuchs et al. 1991; Muralidharan \& Badaya 2000; Dhawan et al. 2007; Hodgson et al. 2008; Wang et al. 2009), including Brazil (Bastos et al. 2007). Mealybugs feed by sucking the plant sap and causing leaf senescence and premature leaf fall, as well as reduced growth and even plant death (Culik \& Gullan 2005). Mealybugs can also cause indirect damage because they can vector plant pathogens such as viruses (Culik \& Gullan 2005 ) and secrete honeydew on the leaves and the open lint, which can seriously endanger the cotton yield. In addition, the honeydew favors the development of black sooty mold fungus, which affects plant development and results in stick lint, causing problems in the spinning process at the textile mills (Hendrix et al. 2001). The mealybugs are considered major pests of cotton in Pakistan and India, with three main species recorded: Phenacoccus solenopis Tinsley, 1898, Ferrisia virgata (Cockerell, 1893), and Maconellicoccus hirsutus (Green, 1908) (Dhawan et al. 2007). These mealybugs species exhibit close morphological traits and, therefore, are hard to identify at species level. However, morphological characteristics can be of practical use to separate them, as described in Williams \& Granara de Willink (1992) and Miller (1999). Briefly, the striped mealybug, F. virgata, has a grayish body, with two uneven lines of dark spots on the dorsum (seen when the wax cover is taken out), two caudal wax filaments nearly at one-half of their body length and many long crystalline rods in adult females. The cotton mealybug, $P$. solenopsis, has depressions on the wax layer covering the body, allowing visualization of pairs of dark spots in the dorsum, and many short lateral wax filaments and caudal filaments at one-quarter of their body length. The pink hibiscus mealybug, $M$. hirsutus, exhibits a fine layer of wax, revealing a pink body due to the reddish hemolymph, and also it has one pair of short caudal filament, the lateral filaments being absent or rarely one or two present.

In Brazil, all these three mealybug species have been recorded in cotton and in other plants (Bastos et al. 2007; SilvaTorres et al. 2013; Culik et al. 2013). Recently, infestations of striped mealybug were found in cotton plants in the semiarid region of Pernambuco. This was the first record of $F$. virgata on cotton in Brazil (Torres et al. 2011). The striped mealybug has also been recorded in the state of Espírito Santo (Williams \& Granara de Willink 1992) as well as M. hirsutus (Culik et al. 2013). Thus, bioecological studies are needed to develop integrated pest management strategies for $F$. virgata on cotton.

For acceptance of the host plant by an insect herbivore, I) there must be insect attraction and establishment on the host plant; II) the insect needs to start and remain feeding on the plant and/or egg laying; and III) the insect and its progeny must complete development on the plant (Schoonhoven et 
al. 2005). The morphological and chemical plant characteristics also influence the degree of association between the herbivore and its host plant. The presence of leaf trichomes, leaf texture variations, as well as the presence and the quantity of glands, such as the gossypol glands in the cotton plant, may or may not favor the establishment, development, and reproduction of insect herbivores (Painter 1958). Therefore, finding cotton cultivars that may be less negatively affected by $F$. virgata may help decide the most suitable cultivar for planting. This control method, which uses cultivars with lower susceptibility to $F$. virgata, helps pest management, especially in semi-arid region of Pernambuco, where the cotton cultivation is done by small producers who use low chemical inputs.

In this context, this study evaluated the establishment, population growth, and within-plant distribution of $F$. virgata on four cotton cultivars recommended for the semi-arid region of Brazil.

\section{MATERIAL AND METHODS}

Experiments were conducted in the Universidade Federal Rural de Pernambuco (UFRPE) in greenhouses (6 m length $\times 2 \mathrm{~m}$ width $\times 2 \mathrm{~m}$ height) laterally closed with antiaphid screen and covered with agricultural plastic. During the experiments, environmental conditions were monitored with DataLogger Hobo ${ }^{\circledR}$ at intervals of 30 min, registering an average temperature of $28.8^{\circ} \mathrm{C}\left(\min =20.9^{\circ} \mathrm{C}, \max =\right.$ $48.4^{\circ} \mathrm{C}$ ), $54 \% \mathrm{RH}$, and natural photoperiod of $12: 12 \mathrm{~h}(\mathrm{~L}: \mathrm{D})$.

Cotton plants of the cultivars CNPA $7 \mathrm{H}$ (white fibers), BRS Verde, BRS Rubi, and BRS Safira (colored fibers) were grown in 5-L plastic pots. A mixture of soil and humus (2:1) was used for planting, in which $5 \mathrm{~g}$ of N:P:K fertilizer (0414-08) was added per pot. In addition, 15 and 25 days after plant emergence, $40 \mathrm{ml}$ of ammonium sulfate solution (10 g/ L) (Fertine, Fertilizantes do Nordeste Ltda, Recife, PE) was added per pot.

Population growth of $\boldsymbol{F}$. virgata on cotton. Cotton plants of the four cultivars (aged 40 days) were infested with 100 first-instar nymphs of $F$. virgata (crawlers). Nymphs were obtained from the laboratory stock colony maintained on pumpkin [Cucurbita moschata (Duch.) Duch. Ex Poir] variety Jacarezinho. Thus, leaf discs (4.8-cm diameter) were cut from cotton plants of the corresponding cultivar (CNPA 7H, BRS Verde, BRS Rubi, and BRS Safira) and placed for about 15 min on pumpkins infested with $F$. virgata to promote the infestation of leaf discs with newly hatched nymphs. According to Silva-Torres et al. (2013), crawlers of F. virgata actively search for a suitable site to establish themselves on the host plant. This behavior facilitates the grouping of nymphs on leaf discs to further carry out the infestation of cotton plants in the greenhouse. Next, the number of nymphs in each leaf disk was determined using a stereomicroscope (OPTON-NTB 3A). After counting the infested leaf discs, they were individually placed over the first-top expanded leaf of each cotton plant. Leaf discs were attached to the cotton plant using a metal paper clip. To prevent ants and other opportunistic arthropods climbing on the plants, entomological glue (BioStop Cola ${ }^{\circledR}$ ) was applied to the base of the main stem of each plant.

The experiment was conducted in a completely randomized design with four treatments, represented by the four cotton cultivars and 18 plants per cultivar. From those, 13 plants per cultivar were evaluated after 25 days of infestation, and the remaining five plants per cultivar were evaluated after 50 days of infestation, because the sampling procedures were destructive. The number of females (individuals with reproductive capacity) was evaluated after 25 days of infestation $(n=13)$, and the total number of mealybugs (nymphs and adults) were evaluated after 50 days of infestation $(n=5)$. To count the number of insects, the plants were collected, packed in plastic bags, and carried to the laboratory for complete inspection with the help of a stereomicroscope. The establishment rate of nymphs was evaluated after 25 days of infestation. It was calculated by the ratio of the number of females present on the plants and the number of nymphs initially released per plant. In addition, the offspring number was counted 50 days after plant infestation. For this, seven plants of each cultivar were previously randomly selected and received adult females (aged 20 days). Two adult females were transferred (with the help of a soft paint brush) from the initial infested leaf to two others clean leaves located in the middle part of the same plant to confine one female per leaf. The leaf petiole received entomological glue to confine and monitor the females. Therefore, each replication consisted of the average number of descendants produced by two females per plant; hence, a total of $14 \mathrm{fe}$ males were evaluated. Females were monitored daily to record the beginning of reproduction, which was characterized by the presence of ovisacs and first-instar nymphs around the female body. Moreover, the eggs were not observed because nymphs hatch within $4 \mathrm{~h}$ (Rawat \& Modi 1969; Awadallah et al. 1979). Thus, the presence of first-instar nymphs defines the end of the pre-oviposition period of $F$. virgata. In addition, the survival of foundress females aged up to 50 days was determined. Finally, when foundress females reached the age of 50 days, their leaves were cut and dispatched to the laboratory, where the number of offspring was determined.

From the results of the number of offspring at 50 days, the instantaneous rate of population growth of $F$. virgata was calculated for the four cotton cultivars, applying the following formula: $r_{i=} \operatorname{Ln}\left(\mathrm{N}_{\mathrm{f}} / \mathrm{N}_{0}\right) / \Delta \mathrm{t}$, where, $\mathrm{Nf}$ is the final number of individuals; $\mathrm{N}_{0}$ is the number of nymphs released by plant; and $\Delta \mathrm{t}$ is the time from infestation to evaluation (25 and 50 days, respectively).

The establishment rate, the average number of mealybugs after 50 days of infestation, and the development time and pre-reproductive period of females on cotton plants of the four cultivars were submitted to analysis of variance through PROC ANOVA of SAS, followed by Tukey's HSD test $(P=$ 0.05 ) for mean comparisons (SAS Institute 2001). Survival curves were determined for mealybugs reared on each cot- 
ton cultivar using the Kaplan-Meier method, and the curves were compared using the Wilcoxon test $(P=0.05)$ by the PROC LIFETEST of SAS (SAS Institute 2001).

Distribution of $\boldsymbol{F}$. virgata within cotton plants. Different cotton cultivars aged 40 days were infested as previously described. After 25 days of plant infestation (age 65 days), the number of females on the infestation leaf, other leaves, the main and lateral stems, and the squares was quantified. After 50 days of infestation, the number of mealybugs present on the leaves, the main and lateral stems, as well as on the reproductive structures was counted.

Twelve cotton plants of each cultivar were infested with mealybugs to evaluate the vertical distribution of $F$. virgata on plants. The infestation followed two procedures: six plants received mealybugs on the first-top expanded leaf and the other six plants received mealybugs on the penultimate leaf in the basal plant stratum. After 50 days of infestation (90day-old plants), the total number of mealybugs was quantified in the upper, middle, and lower plant strata, covering all plant structures such as leaves, stems, squares, and bolls. The vertical distribution of mealybugs found on plants - on the lower, middle, and upper strata - was based on the number of nodes per plant divided by three.

Data on the number of insects on plant structures or strata were transformed to proportion as a function of the total number of insects found and compared between structures or strata using the chi-square test $(P=0.05)$ through the PROC FREQ of SAS (SAS Institute 2001).

\section{RESULTS}

Population growth of $\boldsymbol{F}$. virgata on different cotton cultivars. After 25 days of plant infestation with 100 mealybug crawlers, the average number of established mealybugs ranged from $12.8 \pm 1.96$ to $21.6 \pm 4.28$ females per plant without difference among cotton cultivars $\left(\mathrm{F}_{\text {d.f. }=3,48}=1.57, \mathrm{P}\right.$ $=0.2075)$. Similarly, there was no difference in the average number of individuals per plant after 50 days of infestation of cotton cultivars $\left(\mathrm{F}_{\text {d.f. }=3,20}=0.33, \mathrm{P}=0.8013\right)$. The average number of mealybugs per plant after one generation ranged from $6702.8 \pm 1757.83$ to $8806.8 \pm 1897.23$ individuals, irrespective of the cotton cultivar.

The population growth of $F$. virgata was positive in the four cultivars (Rubi, $r_{i}=0.08 \pm 0.004$; BRS Safira, $r_{i}=0.07 \pm$ 0.007 ; BRS Verde $\mathrm{r}_{i}=0.08 \pm 0.005$, and CNPA 7 $\mathrm{H} \mathrm{r}_{i}=0.08 \pm$ $0.002)$. Therefore, the average growth was estimated as being $>75$ times (7697.2/100 neonates) the initial infestation of 100 nymphs. Moreover, considering only the individuals who were found/established 25 days after infestation (average of 18.7), the population growth was 411.6 times in a single generation (average of 7697.2/18.7).

Females of $F$. virgata showed similar development and pre-reproductive periods when reared on the four cotton cultivars $\left(\mathrm{F}_{\text {d.f. }=3,60}=1.42, \mathrm{P}=0.2449\right)$, as well as the average number of offspring per female $\left(\mathrm{F}_{\text {d.f. }=3,48}=1.32, \mathrm{P}=0.2761\right)$. On average, $F$. virgata reproduction started at $32.0 \pm 0.39$ days $(31.65 \pm 0.37-32.75 \pm 0.55)$ after emergence and produced $376.0 \pm 24.45$ (317.4-438.9) descendants/female. On the other hand, the average survival of females 50 days after initial plant infestation was superior when nymphs developed on the cultivars BRS Safira and BRS Verde (49.7 \pm 0.25 and $48.1 \pm 0.75$ days, respectively) as compared to the cultivars BRS Rubi and CNPA 7H (46.8 \pm 0.8 and $45.9 \pm 0.4$ days, respectively) $\left(\chi^{2}=19.92 ; \mathrm{P}=0.0002\right.$, D.F. $\left.=3\right)$.

Distribution of $\boldsymbol{F}$. virgata within cotton plants. After 25 days of infestation, $F$. virgata was found in all plant structures (leaves, stems, and squares). However, there was a significant difference in the melaybug distribution among plant structures $\left(\chi^{2}=78.40, \mathrm{P}<0.0001\right.$, D.F. $\left.=4\right)($ Fig. 1). The highest number of nymphs was found on the leaf of initial infestation with mealybug crawlers $(78.8 \%)$. On other parts of the plant, the frequency of mealybugs found was relatively low, with $9.3 \%$ of nymphs observed on the main stem, $6.5 \%$ on the leaves, $3.5 \%$ on the lateral stems, and $1.94 \%$ on the squares; there was no significant difference among them $\left(\chi^{2}=\right.$ $2.95, \mathrm{P}=0.3987$, D.F. $=3$ ).

In contrast, 50 days after infestation, the number of mealybugs found on plant structures showed a partial difference ( $5 \%<\alpha<10 \%$ probability), with the highest number of insects found on the leaves $(42.8 \%)$, followed by the main stem $(20.0 \%)$, the lateral stems $(18.6 \%)$, and the bolls $(18.5 \%)$ $\left(\chi^{2}=7.37, \mathrm{P}=0.0607\right.$, D.F. $\left.=4\right)($ Fig. 1).

The vertical distribution of $F$. virgata population on cotton plants 50 days after infestation was variable among the three plant strata. Even with infestation occurring in the upper stratum of the plant, mealybugs were mostly found in the lower stratum $\left(\chi^{2}=6.22, \mathrm{P}=0.044\right.$, D.F. $\left.=2\right)$, followed by the middle stratum and the upper stratum, although there was no difference in the values for the upper and middle strata (Fig. 2). When the infestation occurred in the lower stratum, the highest frequency of mealybugs was also found in this stratum $\left(\chi^{2}=12.07 ; \mathrm{P}=0.0024 ;\right.$ D.F. $\left.=2\right)$ (Fig. 2$)$.

\section{DISCUSSION}

The number of mealybugs found 25 and 50 days after infestation was similar among cultivars, suggesting that the four cotton cultivars have similar susceptibility to Ferrisia virgata. According to Normark and Johnson (2011), F. virgata is considered a polyphagous species that feeds on 20 or more families of vascular plants. Therefore, it is possible that $F$. virgata has mechanisms to tolerate or overcome defensive traits of various plants. Probably, the morphophysiological variations between cotton cultivars studied, such as the presence of leaf trichomes (Breda 2011), were not sufficient to cause changes in F. virgata development. Similar results were also found by Fernandes et al. (2001) in their study on the population growth of the cotton aphid Aphis gossyppii Glover, 1877 (Hemiptera, Aphididae) in different cotton cultivars. In addition, there was a similar population density across studied cultivars at 15, 30, and 45 days after infestation. According to them, the morphological variations among cultivars, such as leaf size, texture, presence of 

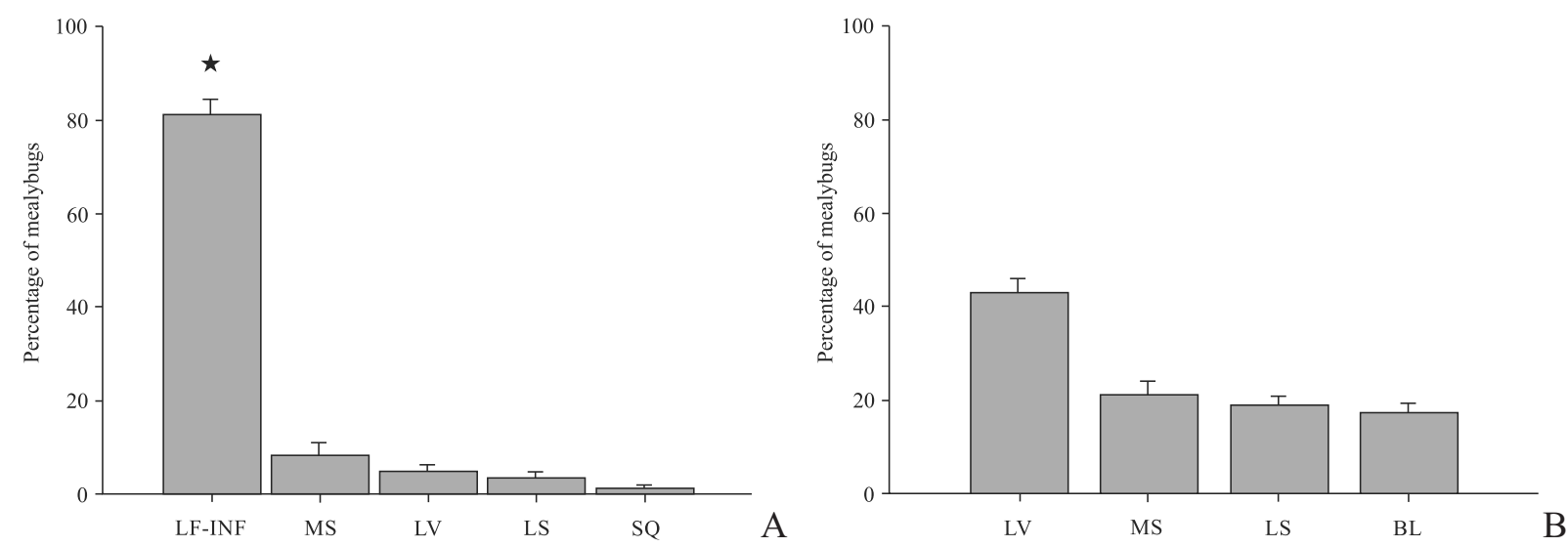

Fig. 1. (A) Distribution of female Ferrisia virgata in different parts of cotton plant 25 days after infestation of crawlers on four cultivars. (B) Distribution of nymphs and of adults 50 days after infestation. Clustered results for cultivars due to the lack of effect of cultivars on distribution. *Indicates difference among parts of the plant through the chi-square test for the hypothesis of equal distribution (A: $\chi^{2}=78.40, \mathrm{P}<0.0001$, D.F. $=4$; B: $\chi^{2}=7.37$, $\mathrm{P}=0.0607$, D.F. $=3$ ). Leaf of infestation (LF-INF), main stem (MS), lateral stem (LS), leaves (LV), square (SQ), and boll (BL).
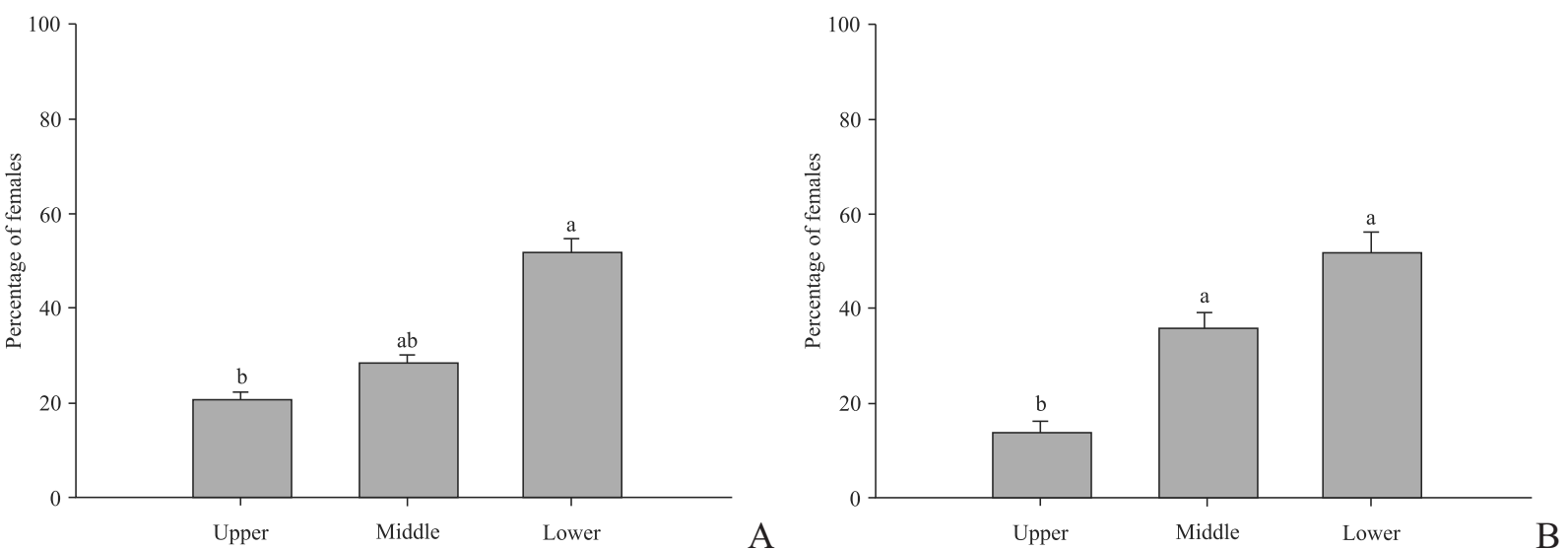

Fig. 2. Averages of the vertical distribution of Ferrisia virgata obtained on four cotton cultivars 50 days after infestation of crawlers in upper (A) and lower (B) strata of the plants. Bars under different letters indicate the differences through the chi-square test at $5 \%$ probability $\left(\mathrm{A}\right.$ : Three strata; $\chi^{2}=$ $6.22, \mathrm{P}=0.044$, D.F. $=2$; upper versus middle, $\chi^{2}=0.65 ; \mathrm{P}=0.4168$, D.F. $=1$; middle versus lower, $\chi^{2}=2.69, \mathrm{P}=0.1009$, D.F. $=1$; upper versus lower, $\chi^{2}=6.0, \mathrm{P}=0.0143$, D.F. $=1$ ); (B: three strata, $\chi^{2}=12.07, \mathrm{P}=0.0024$, D.F. $=2$; upper versus middle, $\chi^{2}=4.99, \mathrm{P}=0.0254$, D.F. $=1$; middle versus lower, $\chi^{2}=1.49, \mathrm{P}=0.2213$, D.F. $=1$; upper versus lower, $\chi^{2}=11.86, \mathrm{P}=0.0006$, D.F. $\left.=1\right)$

trichomes, and plant growth rate, probably did not influence the development of aphids, as observed here for F. virgata.

Mealybugs were found on all plant structures 25 days after infestation, but, the highest numbers were found on the leaf where crawler nymphs were released, suggesting that, initially, the crawlers settle down to feed in the first suitable place within the host plant, even if the chosen site/structure is not considered the best protected place against the attack of natural enemies. Similarly, widespread infestation was observed for the species $P$. solenopsis (Aheer et al. 2009), Planococcus minor (Maskell, 1897) (Hemiptera, Pseudococcidae) (Bastos et al. 2007), and M. hirsutum (Muralidharan \& Badaya 2000) on cotton plants. In the time interval of 25 days, an irregular distribution of mealybugs was observed within the plant, and the highest density was found on the leaves. In another study, McLeod et al. (2002) evaluated the distribution of the mealybugs Dysmicoccus sp. on banana plants (Musa paradisiaca), and reported presence of $85 \%$ of mealybugs on the pseudostem.
In our study, it is possible that the predominant establishment of mealybugs occurred on the leaves of the cotton plants because of the low dispersal activity of mealybugs and by the suitable conditions found on the leaves. Crawlers can also disperse passively by the wind and water, as well as by agriculture tools, to reach higher distances not only between plants but also between fields (Silva-Torres et al. 2013). In this study, it was observed that, immediately after leaf infestation, crawlers settled down on this same structure. Nymphs established on the same place where they were released or few inches away from it. Besides the low self-dispersing capacity, which could have helped $F$. virgata establish on the leaves of infestation, leaf tenderness could also have affected nymphs establishment, as the tenderness facilitates penetration of the mouthparts, which is difficult on hard plant structures such as stems and bolls. Wardhaugh et al. (2006) found that the diameter and thickness of plant structures may influence the establishment of mealybugs. They verified higher densities 
of Ultracoelostoma assimile (Maskell, 1890) (Hemipera, Margarodidae) on branches than on the trunks of the tree Nothofagus fusca (Nothofagaceae). Branches had smaller diameter and bark thickness, which are crucial for colonization, because mealybugs prefer to settle on plant structures such that the phloem cells are located closer to the surface. This could also explain our results, since lower mealybug density was found on stems in comparison to the cotton leaves. Understanding the short-range dispersal of mealybugs within or between neighbor plants is as important as long-range dispersal, because it is essential to predict the course of infestation in the field and to define management strategies (Rabkin \& Lejeune 1954; Loxdale et al. 1993; Barrass et al. 1994). The dispersal of Pseudococcus maritimus (Ehrhorn, 1900) (Hemiptera, Pseudococcidae) on grapevines reported by Grasswitz and James (2008) was similar to that of $F$. virgata on cotton.

Fifty days after infestation, the females reproduced and their offspring were found throughout the plant. Probably, the high density of F. virgata on the leaves, especially after reproduction, stimulated the within-plant displacement of crawlers to places with less competition for resource or space. Furthermore, it is possible that crawlers searched for younger plant structures, because the infested leaves, where foundresses developed were either senescent (approximately 30-day-old) or injured by mealybug feeding.

Highest densities of mealybugs were observed in the middle and lower strata 50 days after infestation. This result may have been determined by the dispersion behavior of $F$. virgata and by the plant growth. Possibly, the nymphs quickly settled at sites with leaf infestation, as explained earlier. In addition, when infestation occurred on the upper or lower strata, the distribution of $F$. virgata was possibly determined by the plant growth because of the following: 1) when the infestation occurred in the upper stratum, due to the plant growth during 50 days, the upper stratum became the middle or the lower stratum. Approximately 32 days after infestation, mealybugs started to reproduce and crawlers dispersed throughout the plant, inducing the presence of $F$. virgata on those strata (Oliveira et al. 2014); 2) when the infestation occurred in the lower stratum, even with the plant growth during the period of 50 days, the infestation stratum remained the same. This occurred because new nodes are produced in the apical part of the plant, and, after plant growth, these nodes previously grouped in the middle stratum, were grouped in the lower stratum. After reproduction, it is possible that crawlers moved to the middle stratum due to their negative geotropic behavior (Gullan \& Kosztarab 1997). Similar results were found by Silva-Torres et al. (2013), who verified under field conditions observed the highest frequency of mealybugs in the middle and lower strata of cotton plants after 60 days of artificial infestation (cv. BRS Rubi) with crawler nymphs of $F$. virgata. When McLeod et al. (2002) studied the vertical distribution of mealybugs on banana plants, they also found highest densities of mealybugs in the middle stratum of the pseudostem. However, for aphids and mites, which are arthropods that have a higher mobility than mealybugs, highest population densities were found in the upper and middle strata of cotton plants after $\geqslant 50$ days of infestation (Carey 1982; Fernandes et al. 2001). These arthropods move to the top of the plant to search for younger structures with best nutritional quality and use air currents for dispersal. Different from insects with higher mobility that take advantage of this characteristic to optimize their dispersal, $F$. virgata nymphs move only to find a suitable site for their development.

In this study, F. virgata showed a high reproductive potential in cotton plant in one single generation. This high population growth caused deformation and death of many plants at the end of the experiment after 50 days of infestation and after 90 days of plant emergence, seriously compromising the yield, although the plants were cultivated under suitable conditions of soil moisture and fertilization. According to our results, $F$. virgata can be considered as a new threat to cotton in Brazil. However, field studies are needed to evaluate the potential of $F$. virgata in causing cotton yield reduction when interacting with other biotic and abiotic factors. Our results also suggest the possibility of significant losses caused by high infestations of $F$. virgata on cotton fields in the northeast semi-arid of Brazil. Furthermore, the present study recorded the highest densities of $F$. virgata on the leaves of 65-day-old plants and in the lower and middle strata of 90 -day-old plants. This indicates that the mealybug distribution on the plant can be correlated with the site of infestation, suitability of the plant structure, and plant age. This study helped us understand the dispersal behavior of $F$. virgata within the cotton plant. It also indicates the sites where the mealybugs can be found on the cotton plant and helps estimate the infestation level.

\section{ACKNOWLEDGMENTS}

This research was partially supported by the agencies Fundação de Amparo à Ciência e Tecnologia do Estado de Pernambuco (FACEPE) and the Coordenação de Aperfeiçoamento de Pessoal de Nivel Superior (CAPES) through the projects APQ-0538-5.01/10 and PNPD No. 02544/09-1, respectively. Also, we thank Alessandra Rung (Plant Pest Diagnostics Branch, California Department of Food and Agriculture, Sacramento, CA) and Douglas Miller (Systematic Entomology Laboratory, ARR-USDA, Beltsville, MD) for identifying the striped mealybug species.

\section{REFERENCES}

Aheer, G.M., Shah, Z. \& Saeed, M. 2009. Seasonal history and biology of cotton mealybug, Phenacoccus solenopsis Tinsley. Journal of Agricultural Research 47: 423-431.

Awadallah, K.T., Ammar, E.D., Tawfik, M.F.S. \& Rashad, A. 1979. Lifehistory of the white mealy-bug Ferrisia virgata (Ckll.) (Homoptera, Pseudococcidae). Deutsche Entomologische Zeitschrift 26: 101-110.

Barrass, I.C., Jerie, P. \& Ward, S.A. 1994. Aerial dispersal of first- and second-instar longtailed mealybug, Pseudococcus longispinus 
(Targioni Tozzetti) (Pseudococcidae: Hemiptera). Australian Journal of Experimental Agriculture 34: 1205-1208.

Bastos, C.S., Almeida, R.P., Vidal Neto, F.C. \& Araújo, G.P. 2007. Ocorrência de Planococcus minor Maskell (Hemiptera: Pseudococcidae) em algodoeiro no Nordeste do Brasil. Neotropical Entomology 36: 625-628.

Breda, M.O. 2011. Efeitos letais e subletais de inseticidas botânicos sobre Aphis gossypii Glover (Hemiptera: Aphididae) e Cycloneda sanguinea (Linnaeus) (Coleoptera: Coccinellidae) em cultivares de algodão de fibra branca e colorida. M.Sc. Dissertation, Universidade Federal Rural de Pernambuco.

Carey, J.R. 1982. Within-plant distribution of tetranychid mites on cotton. Environmental Entomology 11: 796-800.

Culik, M.P \& Gullan, P.J. 2005. A new pest of tomato and other records of mealybug (Hemiptera: Pseudococcidae) from Espírito Santo, Brazil. Zootaxa 964: 1-8.

Culik, M.P., Martins, D.S., Zanuncio Junior, J.S., Fornazier, M.J., Ventura, J.A., Peronti, A.L.B.G. \& Zanuncio, J.C. 2013. The invasive hibiscus mealybug Maconellicoccus hirsutus (Hemiptera: Pseudococcidae) and its recent range expansion in Brazil. Florida Entomologist 96: 638-640.

Dhawan, A.K., Singh, K., Saini, S., Mohindru, B., Kaur, A., Singh, G. \& Singh, S. 2007. Incidence and damage potential of mealy bug, Phenacoccus solenopsis Tinsley on cotton in Punjab. Indian Journal of Ecology 34: 100-109.

Fernandes, A.M.V., Farias, A.M.I., Soares, M.M.M. \& Vasconcelos, S.D. 2001. Desenvolvimento do pulgão Aphis gossypii Glover (Hemiptera: Aphididae) em três cultivares do algodão herbáceo Gossypium hirsutum L. r. latifolium Hutch. Neotropical Entomology 30: 467-470.

Fuchs, T.W., Stewart, J.W., Minzenmayer, R. \& Rose, M. 1991. First record of Phenacoccus solenopsis Tinsley in cultivated cotton in the United States. Southwestern Entomologist 16: 215-221.

Grasswitz, T.R. \& James, D.G. 2008. Movement of grape mealybug, Pseudococcus maritimus, on and between host plants. Entomologia Experimentalis et Applicata 129: 268-275.

Gullan, P.J. \& Kosztarab, M. 1997. Adaptations in scale insects. Annual Review of Entomology 42: 23-50.

Hendrix D.L., Henneberry, T.J., Chu, C.C. \& Coates, W.E. 2001. Enzyme treatment of honeydew-contaminated cotton fiber. Applied Engineering in Agriculture 17: 571-576.

Hodgson, C., Abbas, G., Arif, M.J., Saeed, S. \& Karar, H. 2008. Phenacoccus solenopsis Tinsley (Sternorrhyncha: Coccoidea: Pseudococcidae), an invasive mealybug damaging cotton in Pakistan and India, with a discussion on seasonal morphological variation. Zootaxa 1913: 1-35.

Loxdale, H.D., Hardie, J., Halbert, S., Foottit, R., Kidd, N.A.C. \& Carter, C.I. 1993. The relative importance of short- and long-range movement of flying aphids. Biological Reviews 68: 291-311.
McLeod, P., Diaz, J., Vasquez L. \& Johnson, D.T. 2002. Within-plant distribution and sampling of mealybugs in plantain var. FHIA 21. Tropical Agriculture 79: 150-153.

Miller, D.R. 1999. Identification of the pink hibiscus mealybug, Maconellicoccus hirsutus (Green) (Hemiptera: Pseudococcidae). Insecta Mundi 13: 189-203.

Muralidharan, C.M. \& Badaya, S.N. 2000. Mealy bug (Maconellicoccus hirsutus) (Pseudococcidae: Hemiptera) out break on herbaceum cotton (Gossypium herbaceum) in Wagad cotton belt of Kachchh. Indian Journal of Agricultural Sciences 70: 705-706.

Normark, B.B. \& Johnson, N.A. 2011. Niche explosion. Genetica 139: 551-564.

Oliveira, M.D., Barbosa, P.R.R., Silva-Torres, C.S.A. \& Torres, J.B. 2014. Performance of the striped mealybug Ferrisia virgata Cockerell (Hemiptera: Pseudococcidae) under variable conditions of temperature and mating. Neotropical Entomology 42: 431-438.

Painter, R.H. 1958. Resistance of plants to insects. Annual Review of Entomology 3: 267-290.

Rabkin, F.B., \& Lejeune, R.R. 1954. Some aspects of the biology and dispersal of the pine tortoise scale, Toumeyella numismaticum (Pettit and McDaniel) (Homoptera: Coccidae). Canadian Entomologist 86: $570-575$.

Rawat, R.R. \& Modi, B.N. 1969. Studies on biology of Ferrisia virgata Ckll. (Pseudococcidae: Homoptera) in Madhya Pradesh. Indian Journal of Agricultural Sciences 39: 274-281.

SAS Institute 2001. SAS/STAT User's guide, version 8.02, TS level 2MO. SAS Institute Inc., Cary, NC.

Schoonhoven, L.M., Van Loon, J.J.A. \& Dicke, M. 2005. Insect Plant Biology. Oxford, Oxford University Press, $421 \mathrm{p}$.

Silva-Torres, C.S.A., Oliveira, M.D. \& Torres, J.B. 2013. Host selection and establishment of striped mealybug, Ferrisia virgata, on cotton cultivars. Phytoparasitica 41: 31-40.

Torres, J.B., Oliveira, M.D. \& Lima, M.S. 2011. Cochonilhas Farinhentas: potenciais problemas para o algodão brasileiro. Informativo REDALGO 005. Recife, Universidade Federal de Pernambuco, 6 p.

Wang, Y.P., Wu, S.A. \& Zhang, R.Z. 2009. Pest risk analysis of a new invasive pest, Phenacoccus solenopsis, to China. Chinese Bulletin of Entomology 46: 101-106.

Wardhaugh, C.W., Blakely, T.J., Greig, H., Morris, P.D., Barnden A., Rickard, S., Atkinson, B., Fagan L.L., Ewers, R.M. \& Didham, R.K. 2006. Vertical stratification in the distribution of the beech scale insect (Ultracoelostoma assimile) in Nothofagus tree canopies in New Zealand. Ecological Entomology 31: 185-195.

Williams, D.J. \& Granara De Willink, M.C. 1992. Mealybugs of Central and South America. London, CAB International, 635 p.

Received 5 July 2013; accepted 13 December 2013

Associate Editor: Adeney F. Bueno 